\title{
SASKATCHEWAN'S ANTI-CROW CAMPAIGN: A RETROSPECTIVE ACCOUNT
}

\section{STUART HOUSTON, 863 University Drive, Saskatoon SK S7N 0J8}

Edward R. Kalmbach, a senior assistant biologist with the U.S. Biological Survey was assigned during World War I, to study the food habits of the American Crow. ${ }^{1} \mathrm{He}$ wisely concluded that "Bounties can not be recommended, neither can a campaign of wholesale destruction." His second project was to make extensive landmark bacteriologic studies of "Western Duck Sickness, a form of Botulism".2

In 1934 and 1935 Kalmbach was sent to the Canadian prairies to investigate the relationship between duck egg predation by the American Crow and the recent continuing drastic drop in duck populations across the prairie provinces. He chose two sites in Saskatchewan, Waterhen Marsh near Kinistino and the pothole country around Prince Albert, and Cooking Lake in Alberta. Kalmbach obtained data on 512 duck nests, of which $49 \%$ hatched successfully. Overall, $31 \%$ were destroyed by crows, but in the first half of the season this figure rose to $47 \%$ of nests and at Waterhen, the locality most affected, crows ate more than half the eggs. ${ }^{3}$ However, Kalmbach stressed caution: "if any crow control were to be exercised, it should be confined to federal, state or privately managed areas to which crows have been attracted in unduly large numbers by the presence of nesting waterfowl and on which the consequent delicate problem of control could be kept in experienced hands." The Saskatchewan Game Branch had encouraged Kalmbach in his study, but the Game Branch, ignoring his expert advice, mounted an energetic campaign against crows and magpies.

This began with a crow and magpie egg collecting contest carried out mainly through the schools. In 1936, for example, all 5000 Saskatchewan schools, 4000 of them one-room schools, were circularized. The 443 schools that participated collected 138,620 crow and magpie eggs. Mary Houston remembers accompanying her brother, sister and two neighbour boys on a horse-and-buggy expedition to collect crow eggs for the Edwards school, south of Dilke. The top schools each received a copy of Taverner's Birds of Canada; in those depression years this was the only means of securing an expensive three dollar book for a rural school library. Edwards school did not qualify within the top 252.

The second arm of the anti-crow campaign encouraged the shooting of crows by paying a bonus for each crow leg handed in. The first 
year, 1936, special leg bands were manufactured for the Fish and Game League, bearing SK-36 and a three-digit number. That year, 836 adult crows were banded and 138 crow bands were handed in. Each band garnered at least $\$ 5$; one random number was worth $\$ 100$, another $\$ 50$ and four $\$ 25$, and a lesser number $\$ 10$. To anyone in the depression, especially students, this was "big money."

Those SK-36 bands lacked an address and generated no recoveries from the United States. Fred Bard therefore used regular US Fish and Wildlife Service bands for the next two years. He felt it was reasonable to test whether a province-wide anti-crow campaign might help to slow the continuing decline in duck populations. Bard and his assistants caught crows in funnel-top traps, then released them, two every $13 \mathrm{~km}$, on roads around the province. In 1937, Bard banded 490 crows, of which 59 were shot that year in Saskatchewan, 13 in later years and 13 in the United States. In 1938, 253 crows were banded; 30 were shot within Saskatchewan, and 6 in Alberta and 5 in the United States, with another 29 within Saskatchewan in later years. In 1938, the top payment dropped to $\$ 50$ and only $\$ 275$ was paid out for the 30 crows and one magpie turned in. Some hunters learned to watch for the glint of sunlight from the aluminum band, and shot banded birds selectively!

Of course, random shooting of

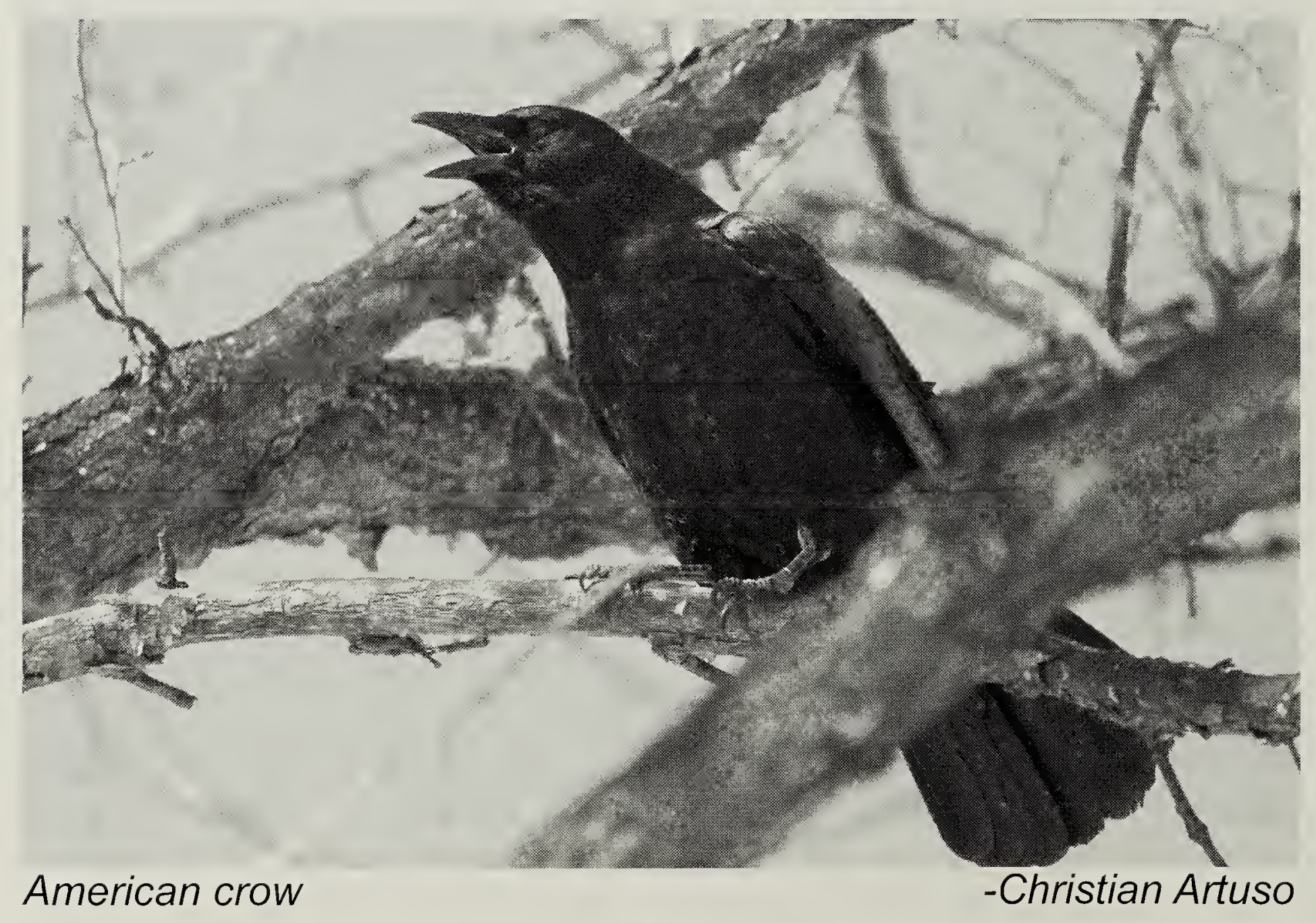


a small percentage of the crow population did not diminish crow numbers nor decrease appreciably the number of duck eggs taken by crows. Yet the school campaign, supported financially by the Saskatchewan Fish and Game League, continued until 1958. The government and the League eventually realized, belatedly, that they were encouraging attitudes of destruction rather than conservation. ${ }^{5}$

The hope of halting the duck population decline by shooting crows persisted among otherwise intelligent duck hunters for forty years. In early April about 1975, a medical colleague proudly boasted to me that he had saved the lives of several hundred ducks the day before. "How?" I enquired. "By shooting four crows, each of which would have eaten a hundred duck eggs." I tried to explain politely his ecological illiteracy, with no understanding of the checks and balances within the "balance of nature." As a hunter, he understood that shooting of $40 \%$ of the Whitetailed Deer or $20 \%$ of the mallards in a given year is "harvesting the crop" and does not diminish their population, so it was beyond my comprehension how he could claim appreciable benefit from shooting four crows. There are parallels today with those who deny climate change, which I prefer to name "climate chaos". 6
One positive achievement resulted from Bard's crow banding: knowledge of the unusually straight south migration of Saskatchewan crows, following the single tier of states from North Dakota to Texas, differing from most other bird species that trend more easterly along the Mississippi. ${ }^{7}$

1. Kalmbach ER (1918) The crow and its relation to man. U.S. Dep. Agric. Bull. 621.

2. Kalmbach ER (1934) Western Duck Sickness, a form of botulism, with bacteriological contributions. U.S. Dept. Agric. Tech. Bull. 411.

3. Kalmbach ER (1937) Crowwaterfowl relationships. U.S. Dep. Agric. Circular 433.

4. Reeves HM (1984) Edward R. Kalmbach, pp. 82-84 In: Flyways: Pioneering Waterfowl Management in North America.

A.S. Hawkins, R.C. Hanson, H.K. Nelson, and H.M. Reeves, eds.

5. Houston CS (1970) Wildlife [crow campaigns]. Fish and Game Sportsman 2(4):36.

6. Lappe FM (2010) Getting a Grip ${ }^{2}$. Small Planet Media, Cambridge, MA.

7. Houston CS (1970) Changing patterns of Corvidae on the prairies. Blue Jay 35(3):149-155. 